\title{
Book Review of \\ DiMino, J. (2019). Shadow Work and Sacred Space: Exploring Myths We Live In. Mimesis Books. 229 p.
}

\author{
Pascal E. Sauvayre \\ William Alanson White Institute \\ 20 West $74^{\text {th }}$ St., New York, New York 10023, United States of America
}

For those of us involved in cross-cultural psychology and mental health, this new book by Mimetic therapist John DiMino offers an unusual adventure.

As an editor with a psychoanalytic journal, I read submissions expecting them to follow a rather conventional and structured format, whereby the author

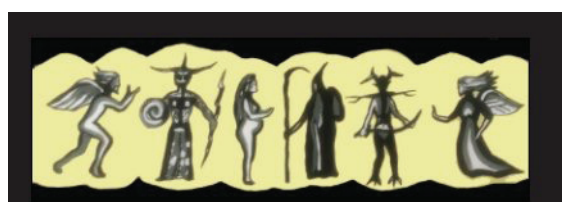

SHADOW WORK

\&

SACRED SPACE

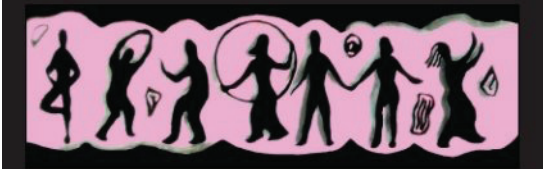

Exploring Myths We Live In John DiMino, Ph. D.

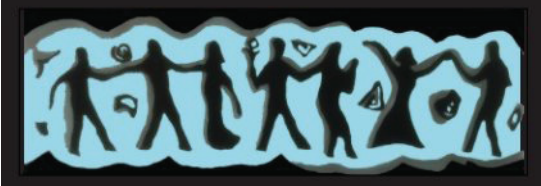
introduces an innovative theoretical formulation, covers the relevant literature, and uses clinical/ experiential material to illustrate his/her argument. That is precisely how not to read Shadow Work and Sacred Space.

Instead, I encountered a much looser associative process that repeatedly frustrated my expectations as I unsuccessfully tried to push the text into my prepared intellectual boxes. As I read the introduction, where one finds Dr. DiMino's exposition of his theoretical inspiration, a seemingly minor detail was tugging at my attention: the page numbering was in roman numerals, which is usually used for prefaces. Eventually, it dawned on me that, like a preface, DiMino's introduction (and therefore the theories he references in it) is not an essential part of the book. As I gave up my prepared boxes, I let myself be drawn into each chapter's stories that take us on a rich cross cultural journey of myths (Greek, Biblical, Native American, Sumerian, Grimm tales...), which are worth the read on their own, for most of us who may not have had this

(C) Sauvayre P.E., 2019

This work is licensed under a Creative Commons Attribution 4.0 International License https://creativecommons.org/licenses/by/4.0/ 
cross cultural exposure to the world's myths. But I devote this space to my process of reading the book (of frustrated expectations followed by a letting go and opening up) because I believe it reflects the Mimesis process itself, the description of which DiMino explains was his "original intention" (p. ii), and "a large part of the book involves presenting a unique group process that uses mimetic play to explore myth and story" (p. 203). I would add that it is also the most powerful part of the book.

Published as an extension of his work as co-director (with his wife Liza) of the Mimesis Center, the chapters take the reader on a freewheeling exploration of existential themes (isolation, power, death, abuse, intimacy, autonomy...) using selected myths as our guides into the "folly of existence" (p. 6). DiMino uses lived experience to bring us to the theme of each chapter, sometimes it is his own, sometimes that of a friend of colleague, and sometimes that of his patients. He then describes a mimetic group experience to deepen the exploration.

Mimetic work so permeates DiMino's thinking and work that he seems to live and breathe it, so much so that he overlooks the fact that most of us do not have a working knowledge of the process. From what I have gathered (and complemented by DiMino through a personal communication), the therapeutic/experiential group process involves the creation of a "play space" (p. 184) with a succession of identifiable steps:

- first, there is the selection of the myth (usually done by the leader, but sometimes involving the group as well) to fit the needs of the group;

- the reading - or telling - of the myth to the group;

- followed by a period of reflection and/or meditation (often guided by the leader with instructions to relate the theme of the myth to their own lives);

- only then comes the staging and acting of the myth in an improvised play by the group members (this includes the selection of roles and so forth);

- and then the process concludes with a group discussion, or debrief, of the members' experiences.

What members find is that their "real" experiences "in life" are "played out" (p. 31) in surprisingly powerful ways through the mediation of the reënactments of myths that group members can participate in staging and acting. Unquestionably, this seems to be a moving and gripping experience; as one participant put it, "it just blows my mind, the deepness, the meaning of that story and the way it was lived out there, there was something very real about the pain and power that we feel. It was very real.” (p. 113).

This is a stunning, but not uncommon, account, and it begs to be explored in more detail. While DiMino's devotion to the mimetic process is obviously necessary for such a book, it also creates a blind spot, however small but still significant, in that it crowds out the exigency to explicate. He is fully aware of this, acknowledging both his difficulty and hesitancy (p. iii; p. 179) to describe the process, let alone explicate it. Even if much of the difficulty lies in the translation of lived experience into explication as DiMino underlines, it is still a valuable undertaking (and the book can be seen as an important step in that direction), however imperfect the explication may be. 
The question, perhaps for DiMino's next book, would be to understand the 'power' of the process our participant refers to above. Much of it can be located 'in' the myth, but that is insufficient. Adding the interpretive involvement of the group members in "discerning the code of mythic texts" (p. vii) takes us much closer to appreciating the dialectical complexity of text and interpreter - as long as we recognize that the 'code' is neither fixed nor pre-written. DiMino understands this well when he points out that the myth loses its creative power when it is taken "at face value" (p. 201), or as the "TRUTH" (p. 202), and instead becomes a destructive force because it then forecloses the multiplicity of interpretations. I would suggest that its enigmatic nature is precisely where it draws its power from the myth functioning not only as code, but more importantly as metaphor, metaphor that calls upon the interpreter to 'work' on its contradictory elements. So when Freud explains that the "gripping power" of the Oedipus play is because "everyone in the audience was once a budding Oedipus in fantasy" (Freud Letter to Fliess of 10/15/1897), just as DiMino explains that mimetic work finds its experiential power in that our "real" experiences are "played out" in the myth, this opens up the question, how does this happen?

The Native American elders explain that the power of myth is drawn out by an "Iyeska, which means interpreter of spirits" (p. 196), which DiMino explains is commonly referred to as a 'medicine man'. I want to emphasize here the interpretive work of the medicine man, and I suggest that the power of the myth is partly put into the play through the 'work' of interpretation by the participant (which can be found in each step of the process: from the selection of the myth to the group discussion - all essentially interpretive activities). My favorite chapter, Abuse and Transformation, demonstrates the complexity of this 'work' because it provides not only different mimetic enactments of the same myth (and different group interpretations), but it also tracks the impact of that experience over time for one of its participants (and therefore the different interpretations she drew from it over time).

As I was writing this review and rereading sections of the book, I came upon the following recommendation on how to read the book: “...in an impressionistic way, the chapters represent the developmental flow of a human life. The chapters can be read in sequence or out depending on one's needs and interest" (p. ii). Apparently, I read right over it, and it took reading (and rereading) the book to open up this defensive expectation, something akin to the mimetic process itself. Commenting upon my experience of reading the book, DiMino emphasizes this point: "The act of going back through and reconsidering... different ways to view things... is something we find again in this work. This new insight... is parallel to the mimetic process itself."

\section{Article history:}

Received: 25 November 2019

Revised: 03 December 2019

Accepted: 05 December 2019 


\title{
For citation:
}

Sauvayre, P.E. (2019). Book Review of DiMino, J. (2019). Shadow Work and Sacred Space: Exploring Myths We Live In. Mimesis Books. 229 p. RUDN Journal of Psychology and Pedagogics, 16(4), 670-673. http://dx.doi.org/10.22363/2313-1683-2019-16-4-670-673

\section{Bio note:}

Pascal E. Sauvayre, Ph.D. in Psychology, is a multilingual author, editor, and a training psychoanalyst at the William Alanson White Institute of Psychiatry, Psychoanalysis \& Psychology (New York City, USA).E-mail: psauvayre@yahoo.com

\section{Рецензия}

\section{Рецензия на книгу \\ DiMino, J. (2019). Shadow Work and Sacred Space: Exploring Myths We Live In. Mimesis Books. 229 p.}

\author{
П.Э. Совэр \\ Институт имени Уильяма Алансона Уайта \\ Соединенные Штаты Америки, 10023, Нью-Йорк, 74-я ул., 20
}

\section{История статьи:}

Поступила в редакцию: 25 ноября 2019 г.

Принята к печати: 05 декабря 2019 г.

\section{Для цитирования:}

Совэр П.Э. Рецензия на книгу DiMino, J. (2019). Shadow Work and Sacred Space: Exploring Myths We Live In. Mimesis Books. 229 p. // Вестник Российского университета дружбы народов. Серия: Психология и педагогика. 2019. Т. 16. № 4. С. 670-673. http://dx.doi.org/10.22363/2313-1683-2019-16-4-670-673

\section{Сведения об авторе:}

Паскаль Э. Совэр, Ph.D., автор, редактор, психоаналитик в Институте психиатрии, психоанализа и психологии имени Уильяма Алансона Уайта (Нью-Йорк, США). E-mail: psauvayre@yahoo.com 